Article

\title{
Rh catalysts supported on knitting aryl network polymers for the hydroformylation of higher olefins
}

\author{
Miao Jiang a,c, Yunjie Ding a,b,*, Li Yan a , Xiangen Song a , Ronghe Lin ${ }^{a}$ \\ a Dalian National Laboratory for Clean Energy, Dalian Institute of Chemical Physics, Chinese Academy of Sciences, Dalian 116023, Liaoning, China \\ b State Key Laboratory for Catalysis, Dalian Institute of Chemical Physics, Chinese Academy of Sciences, Dalian 116023, Liaoning, China \\ c University of Chinese Academy of Sciences, Beijing 100049, China
}

\section{A R T I C L E I N F O}

Article history:

Received 23 January 2014

Accepted 26 February 2014

Published 20 September 2014

Keywords:

Knitting aryl network polymer

Rhodium

Heterogeneous catalyst

Hydroformylation of higher olefins
Triphenylphosphine

\section{A B S T R A C T}

Rh catalysts supported on knitting aryl network polymers (Rh/KAPs) were prepared for the hydroformylation of higher olefins. Rh catalysts supported on triphenylphosphine-benzene-base polymers (Rh/KAPs-1) showed higher activity for the higher olefins than $\mathrm{Rh} / \mathrm{SiO}_{2}$ catalysts. Fourier transform infrared spectroscopy, thermogravimetry, $\mathrm{N}_{2}$ adsorption-desorption, X-ray diffraction, transmission electron microscopy, ${ }^{13} \mathrm{C}$ NMR, and ${ }^{31} \mathrm{P}$ NMR showed that the Rh/KAPs-1 catalysts have high thermal stability, high surface area, hierarchical porosity, highly dispersed Rh nanoparticles, and in situ formed homogeneous active species during the reaction.

(C) 2014, Dalian Institute of Chemical Physics, Chinese Academy of Sciences. Published by Elsevier B.V. All rights reserved.

\section{Introduction}

Hydroformylation is the addition of syngas to olefins to give aldehydes or alcohols [1-3]. It is catalyzed by transition metal complexes and is a successful example of an industrial process in homogeneous catalysis. Although homogeneous catalysts exhibit a higher activity under mild conditions, its industrial application on a large scale is hindered by the separation of the catalyst from the product [4]. The prominent advantage of a heterogeneous catalyst is its easy separation from the product in contrast to a homogeneous catalyst. However, heterogeneous catalysts suffer the problems of low activity and selectivity. As a hot topic, heterogenized homogeneous catalysts for hydroformylation [5-8] have been shown to combine the advantages of homogeneous and heterogeneous catalysts. Solid supports for the heterogenized homogeneous catalysts include inorganic materials (zeolites, activated carbon, silica, etc.) and porous organic polymers. Porous organic polymers have attracted attention for their outstanding properties such as high surface area, low skeletal density, and chemical functionalities in the porous framework [9-11].

Porous organic polymers have unique properties. Compared to inorganic materials, it is easy to introduce chemical functionalities in the porous framework, which is favorable for the synthesis of functional materials. Compared with metal organic frameworks, they have high thermal stability, which is beneficial for heterogeneous catalysis. So far, the porous organic polymers used have been hyper-crosslinked polymers, polymers of intrinsic microporosity, conjugated microporous polymers, and covalent organic frameworks [12]. These porous materials have wide applications in separation and gas storage $[13,14]$ but rare applications in heterogeneous catalysis $[15,16]$.

Knitting aryl network polymers (KAPs) were synthesized by

* Corresponding author. Tel/Fax: +86-411-84379143; E-mail: dyj@dicp.ac.cn 
Tan's group [17-20] in 2011. KAPs were synthesized by a one-step Friedel-Crafts reaction using triphenylphosphine as the monomer, aromatic compounds as the co-monomer, and formaldehyde dimethyl acetal as the external cross-linker. KAPs have the advantages of a simple synthesis method, cheap reagents, and different kinds of monomers that give diverse functional polymers. Here we report KAPs supported Rh catalysts (Rh/KAPs) for the hydroformylation of higher olefins.

\section{Experimental}

\subsection{Synthesis of KAPS}

Four KAPs samples were synthesized using different co-monomers. Formaldehyde dimethyl acetal ( $9.12 \mathrm{~g}, 0.12 \mathrm{~mol})$ and anhydrous $\mathrm{FeCl}_{3}$ (29.25 g, $0.18 \mathrm{~mol}$ ) were added to a solution of triphenylphosphine (15.75 g, $0.06 \mathrm{~mol}$ ) and benzene ( $4.68 \mathrm{~g}, 0.06 \mathrm{~mol}$ ) in 1,2-dichloroethane $(100 \mathrm{ml})$. The mixture was stirred at room temperature and then stirred at $318 \mathrm{~K}$ for 5 $\mathrm{h}$ to form the original network, which was then heated at $353 \mathrm{~K}$ for $67 \mathrm{~h}$. The precipitate was washed with ethanol three times, then washed with ethanol in a Soxhlet apparatus for $24 \mathrm{~h}$, then dried under vacuum at $343 \mathrm{~K}$ for $24 \mathrm{~h}$, and finally triphenylphosphine-benzene-base polymers (KAPs-1) were obtained.

Using methylbenzene ( $5.52 \mathrm{~g}, 0.06 \mathrm{~mol}$ ) to replace benzene in the solution above, triphenylphosphine-methylbenzene-base polymers (KAPs-2) were obtained via the same synthesis method.

Using biphenyl ( $3.08 \mathrm{~g}, 0.02 \mathrm{~mol})$ to replace methylbenzene in the solution above and changing the amounts of anhydrous $\mathrm{FeCl}_{3}$ and triphenylphosphine to 19.5 and $5.25 \mathrm{~g}$, respectively, triphenylphosphine-biphenyl-base polymers (KAPs-3) were obtained via the same synthesis method.

Using 1,3,5-triphenylbenzene (6.12 g, $0.02 \mathrm{~mol}$ ) instead of biphenyl in the solution above, triphenylphosphine-1,3,5-triphenylbenzene-base polymers (KAPs-4) were obtained via the same synthesis method.

\subsection{Preparation of Rh/KAPs and $\mathrm{Rh} / \mathrm{SiO}_{2}$ catalysts}

The KAPs and $\mathrm{SiO}_{2}$ supports were impregnated with an ethanol solution of $\mathrm{RhCl}_{3}$. The samples were dried at room temperature for $24 \mathrm{~h}$, then dried at $393 \mathrm{~K}$ for $12 \mathrm{~h}$, then reduced by $\mathrm{H}_{2}$ at $453 \mathrm{~K}$ for $4 \mathrm{~h}$, and finally stored under $\mathrm{N}_{2}$. The Rh loading of each catalyst was $1 \mathrm{wt} \%$.

\subsection{Characterization of the catalysts}

Fourier transform infrared (FT-IR) spectra were measured on a Bruker Tensor 27 FT-IR spectrometer. All spectra were recorded with a resolution of $4 \mathrm{~cm}^{-1}, 32$ scans, and in the range 4000-400 $\mathrm{cm}^{-1}$. Thermogravimetric analysis (TG) was performed on a thermal analyzer (Netzsch STA 449F3). The samples were heated at the rate of $10 \mathrm{~K} / \mathrm{min}$ from $293 \mathrm{~K}$ up to 923 $\mathrm{K}$ under $\mathrm{N}_{2}$. The specific surface area was measured using a Quantachrome Instruments Autosorb-1 system. The samples were outgassed at $373 \mathrm{~K}$ for $20 \mathrm{~h}$ before measurement. The pore size distribution curves were obtained from the adsorption branch using the non-local density functional theory (NLDFT) method with the carbon slit pore model. Powder X-ray diffraction (XRD) patterns were recorded with a PANalytical X'pert PRO powder X-ray diffractometer with $\mathrm{Cu} K_{\alpha}$ radiation. The apparatus was operated at $40 \mathrm{kV}$ and $40 \mathrm{~mA}$ using the rate of $10^{\circ} / \mathrm{min}$ and the range of $10^{\circ}-70^{\circ}$. Transmission electron microscope (TEM) images were taken on a JEOL JEM-2000EX electronic microscope. Solid-state ${ }^{13} \mathrm{C}$ MAS NMR experiments were carried out on a VARIAN Infinity plus spectrometer equipped with a $2.5 \mathrm{~mm}$ probe. The spectra were recorded using a delay of $3.0 \mathrm{~s}$ and a magic angle spinning rate of $12 \mathrm{kHz}$. Solid-state ${ }^{31 P}$ MAS NMR were performed on a VARIAN Infinity Plus spectrometer equipped with a $2.5 \mathrm{~mm}$ probe at a frequency of $161.8 \mathrm{MHz}$. The spectra were recorded using a delay of $3.0 \mathrm{~s}$ and a magic angle spinning rate of $10 \mathrm{kHz}$. Solid-state ${ }^{31} \mathrm{P}$ NMR chemical shifts were referenced to $85 \%$ $\mathrm{H}_{3} \mathrm{PO}_{4}$. In situ FT-IR spectra of adsorbed $\mathrm{CO}$ were measured on a Bruker Tensor 27 FT-IR spectrometer. All spectra were recorded with a resolution of $4 \mathrm{~cm}^{-1}, 32$ scans, and in the range $4000-400 \mathrm{~cm}^{-1}$. The samples were reduced by $\mathrm{H}_{2}(40 \mathrm{ml} / \mathrm{min})$ at $393 \mathrm{~K}$ for $1 \mathrm{~h}$, then purified in a flow of $\mathrm{N}_{2}(40 \mathrm{ml} / \mathrm{min})$ for $0.5 \mathrm{~h}$, and then used for FT-IR measurement (spectrum A). Then, CO ( $40 \mathrm{ml} / \mathrm{min}$ ) was introduced for $0.5 \mathrm{~h}$ under atmospheric pressure. Spectrum B was recorded after purging the chamber with $\mathrm{N}_{2}$ for $0.5 \mathrm{~h}$. Subtracting spectrum A from spectrum B gave the FT-IR spectra of adsorbed CO.

\subsection{Hydroformylation reaction}

The hydroformylation of higher olefins was carried out in a $30 \mathrm{ml}$ autoclave. In a typical run, $11.1 \mathrm{mg}$ of catalyst, the desired amount of higher olefins, and $6 \mathrm{~g}$ of toluene were added into the autoclave under $\mathrm{N}_{2}$. The reactor was purged three times with the premixed gas $\left(\mathrm{CO}: \mathrm{H}_{2}=1: 1\right)$ and heated from room temperature to the reaction temperature of $373 \mathrm{~K}$. During the reaction, the pressure in the reactor was held constant (2.0 MPa) by the injection of more premixed gas ( $\left.\mathrm{CO}: \mathrm{H}_{2}=1: 1\right)$ with a pressure regulator. The catalyst was separated by centrifugation. The products were analyzed by an Agilent $7890 \mathrm{~A}$ gas chromatograph with an HP-5 column using an FID detector and propanol as an internal standard.

\section{Results and discussion}

\subsection{Characterization results}

\subsubsection{FT-IR}

Figure 1 shows FT-IR spectra of KAPs obtained using different co-monomers (benzene, methylbenzene, biphenyl, and 1,3,5-triphenylbenzene). The series of peaks around 1600-1450 $\mathrm{cm}^{-1}$ were attributed to the benzene skeleton stretch. The peaks around 1250-950 and 900-650 $\mathrm{cm}^{-1}$ resulted from $\mathrm{C}-\mathrm{H}$ in-plane bending and out-of-plane bending vibrations of the benzene ring. A peak at $1435 \mathrm{~cm}^{-1}$ was due to the vibration of the $\mathrm{P}-\mathrm{CH}_{2}$ bond [21], which showed that tri- 


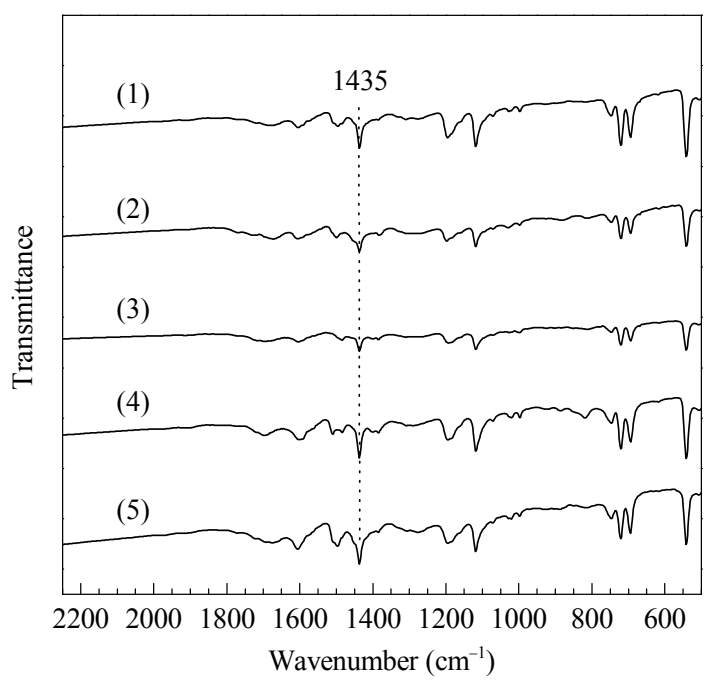

Fig. 1. FT-IR spectra of KAPs prepared from different co-monomers and the Rh/KAPs-1 catalyst. (1) KAPs-1 (from benzene); (2) KAPs-2 (from methylbenzene); (3) KAPs-3 (from biphenyl); (4) KAPs-4 (from 1,3,5-triphenylbenzene) ; (5) Rh/KAPs-1 catalyst.

phenylphosphine was the monomer in the framework of the KAPs. As shown in Fig. 1, no significant difference was observed in the FT-IR spectra of the KAPs- 1 and Rh/KAPs- 1 catalyst. The peak at $1435 \mathrm{~cm}^{-1}$ also existed, which revealed that the KAPs-1 supports were unchanged in the preparation of the catalysts.

\subsubsection{TG analysis}

Thermal stability is a necessary property of the porous polymers for use as supports. The TG analysis (Fig. 2) shows that the Rh/KAPs-1 catalyst has a superior thermal stability with the decomposition temperature of $600 \mathrm{~K}$. The thermal stability of Rh/KAPs-1 was comparable to Nafion NR50, one of the most stable polymers. As is well known, many polymers as the support are limited by their poor thermal stability. However, KAPs as the support can be widely applied in heterogeneous catalysis because of their superior thermal stability.

\subsubsection{Textural properties}

The Rh/KAPs-1 catalyst possessed the highest surface area of the Rh/KAPs catalysts (Table 1). The BET surface area was

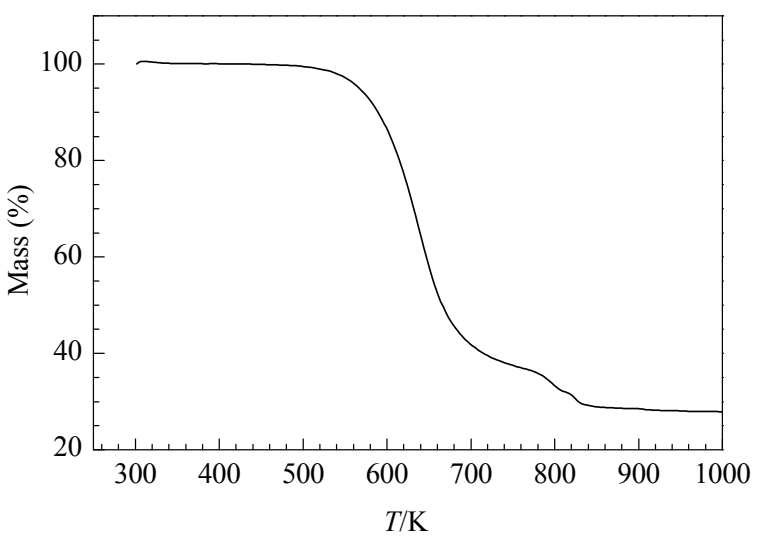

Fig. 2. TG curve of the Rh/KAPs-1 catalyst.
Table 1

Textural properties of the $\mathrm{Rh} / \mathrm{KAPs}$ and $\mathrm{Rh} / \mathrm{SiO}_{2}$ catalysts.

\begin{tabular}{lcc}
\hline Catalyst & BET surface area $\left(\mathrm{m}^{2} / \mathrm{g}\right)$ & Pore volume $\left(\mathrm{cm}^{3} / \mathrm{g}\right)$ \\
\hline Rh/KAPs-1 & 723 & 0.92 \\
$\mathrm{Rh} /$ KAPs-2 & 524 & 0.66 \\
$\mathrm{Rh} /$ KAPs-3 & 672 & 0.70 \\
$\mathrm{Rh} / \mathrm{KAPs}-4$ & 549 & 0.58 \\
$\mathrm{Rh} / \mathrm{SiO}_{2}$ & 187 & 0.84 \\
\hline
\end{tabular}

as high as $723 \mathrm{~m}^{2} / \mathrm{g}$. For comparison, the BET surface area of the $\mathrm{Rh} / \mathrm{SiO}_{2}$ catalyst was $187 \mathrm{~m}^{2} / \mathrm{g}$. The $\mathrm{N}_{2}$ adsorption-desorption isotherms of the Rh/KAPs-1 catalyst are shown in Fig. 3(a). A steep $\mathrm{N}_{2}$ uptake at $p / p_{0}<0.001$ was due to the filling of micropores, while the hysteresis loop was from the contribution of mesopores. A sharp rise at $p / p_{0}=0.6-1.0$ indicated the presence of a macroporous structure. These results demonstrated the hierarchical porosity of the Rh/KAPs-1 catalyst, which was further confirmed by the pore size distribution curves of the Rh/KAPs-1 catalyst (Fig. 3(b)). Actually, hierarchical porosity is beneficial for a heterogeneous catalysis process. A high surface area and abundant micropores are favorable for the dispersion of catalytically active sites, and the macropores accelerate mass transfer in heterogeneous catalysis.

\subsubsection{XRD and TEM analysis}

Figure 4 reveals the XRD patterns of the KAPs- 1 and Rh/KAPs- 1 catalyst. There was only a broad peak, suggesting
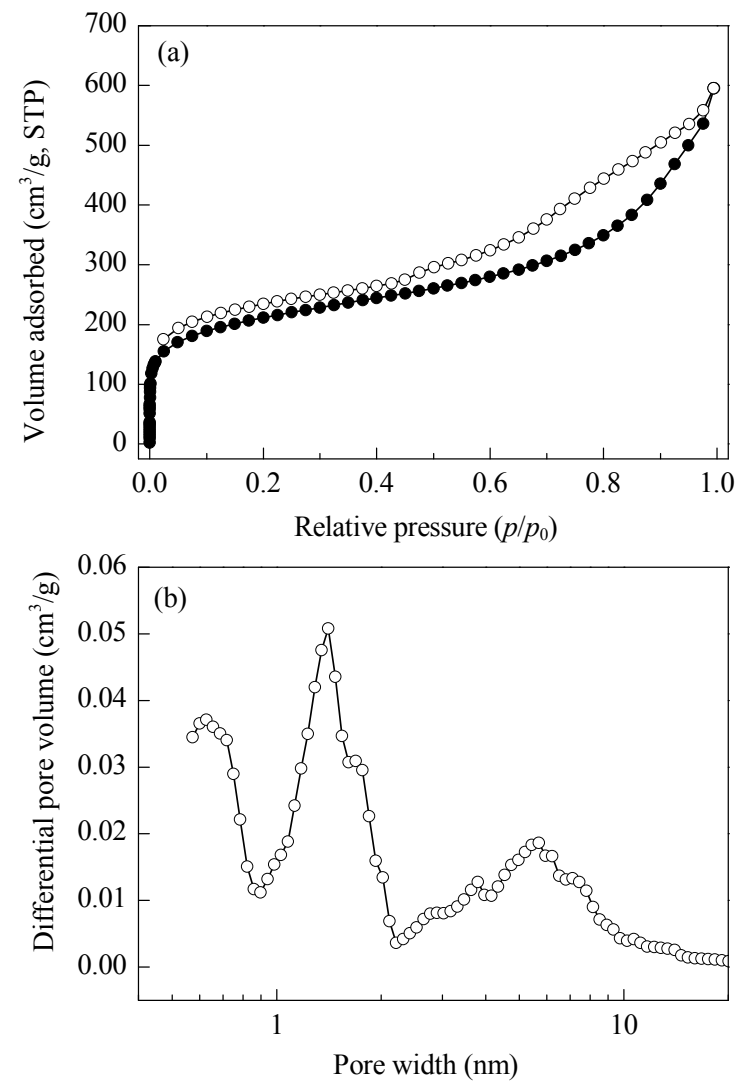

Fig. 3. $\mathrm{N}_{2}$ adsorption-desorption isotherms (a) and pore size distribution (b) of the Rh/KAPs-1 catalyst. 


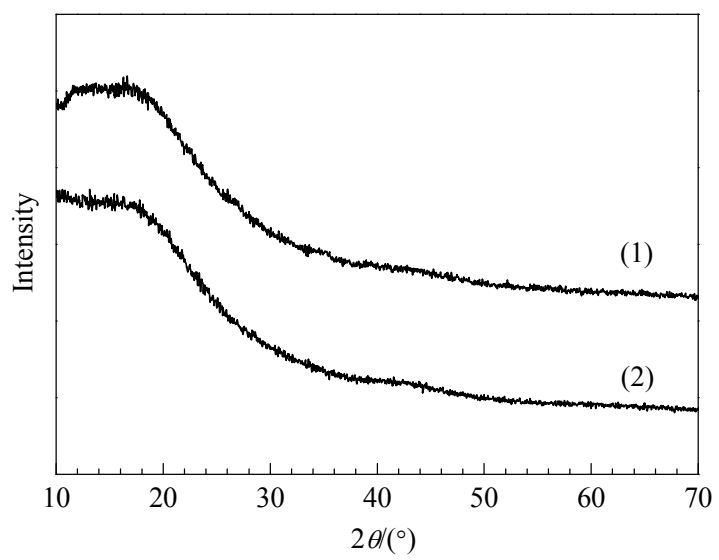

Fig. 4. XRD patterns of the KAPs-1 (1) and Rh/KAPs-1 catalyst (2).

the amorphous structure of KAPs-1. This result may be due to the high dispersion of the Rh species or the low Rh loading of the Rh/KAPs-1 catalyst. TEM images of Rh/KAPs- 1 and $\mathrm{Rh} / \mathrm{SiO}_{2}$ catalysts are shown in Fig. 5 . The $\mathrm{Rh}$ species of the $\mathrm{Rh} / \mathrm{KAPs}-1$ catalyst were better dispersed than those in the $\mathrm{Rh} / \mathrm{SiO}_{2}$ catalyst.

\subsection{5. ${ }^{13} C$ MAS NMR and ${ }^{31} P$ MAS NMR}

The ${ }^{13} \mathrm{C}$ MAS NMR spectra of the Rh/KAPs-1 catalyst (Fig. 6(a)) displayed a resonance peak at $\delta=42.1$ due to the carbon in the methylene linker formed from the Friedel-Crafts reaction. The resonance peaks at $\delta=137.5$ and 129.5 were attributed to substituted aromatic carbon and non-substituted aromatic carbon, respectively [18]. In comparison to KAPs-1 (Fig. 6(b)), the 31P MAS NMR resonance peak of the Rh/KAPs-1 catalyst was shifted from 26.1 to 27.3 , which indicated the coordination of the Rh species with the P atom in KAPs-1 [22,23]. Thus, KAPs-1 possessed not only a high surface area and hierarchical porosity but also the ability to successfully coordinate $\mathrm{Rh}$ species with the phosphorous atom.

\subsubsection{In situ FT-IR characterization of adsorbed CO}

Figure 7 exhibits the in situ FT-IR spectra of adsorbed $\mathrm{CO}$ on the $\mathrm{Rh} / \mathrm{KAPs}-1$ and $\mathrm{Rh} / \mathrm{SiO}_{2}$ catalysts. The peaks of the $\mathrm{Rh} / \mathrm{KAPs}-1$ catalyst at 2081 and $2004 \mathrm{~cm}^{-1}$ resulted from homogeneous active $\mathrm{HRh}(\mathrm{CO})\left(\mathrm{PPh}_{3}\right)_{3}$ species $[24,25]$. In the FT-IR
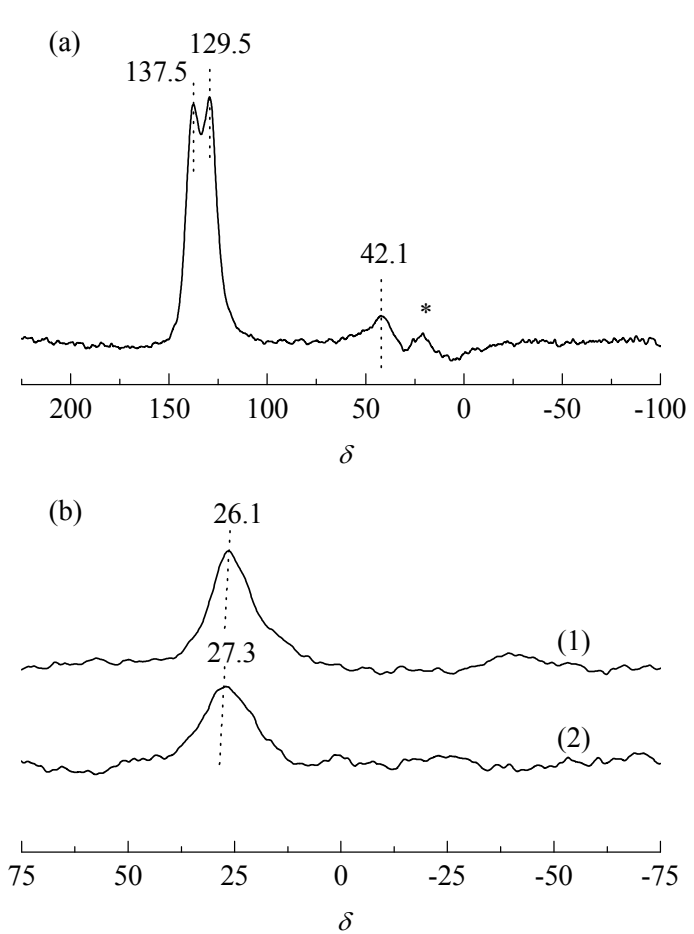

Fig. 6. ${ }^{13}$ C MAS NMR (a) and ${ }^{31}$ P MAS NMR (b) spectra of the KAPs-1 (1) and Rh/KAPs- 1 catalyst (2).

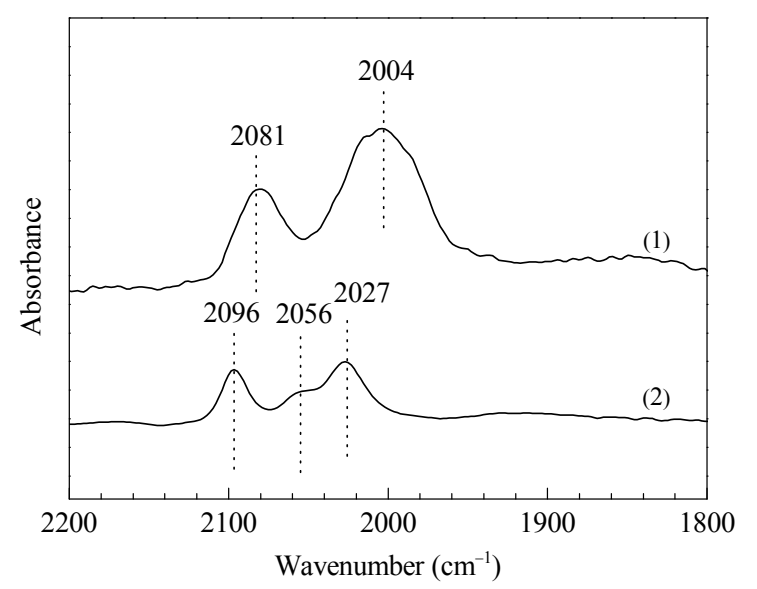

Fig. 7. In situ FT-IR spectra of adsorbed CO on Rh/KAPs-1 (1) and $\mathrm{Rh} / \mathrm{SiO}_{2}(2)$ catalysts.

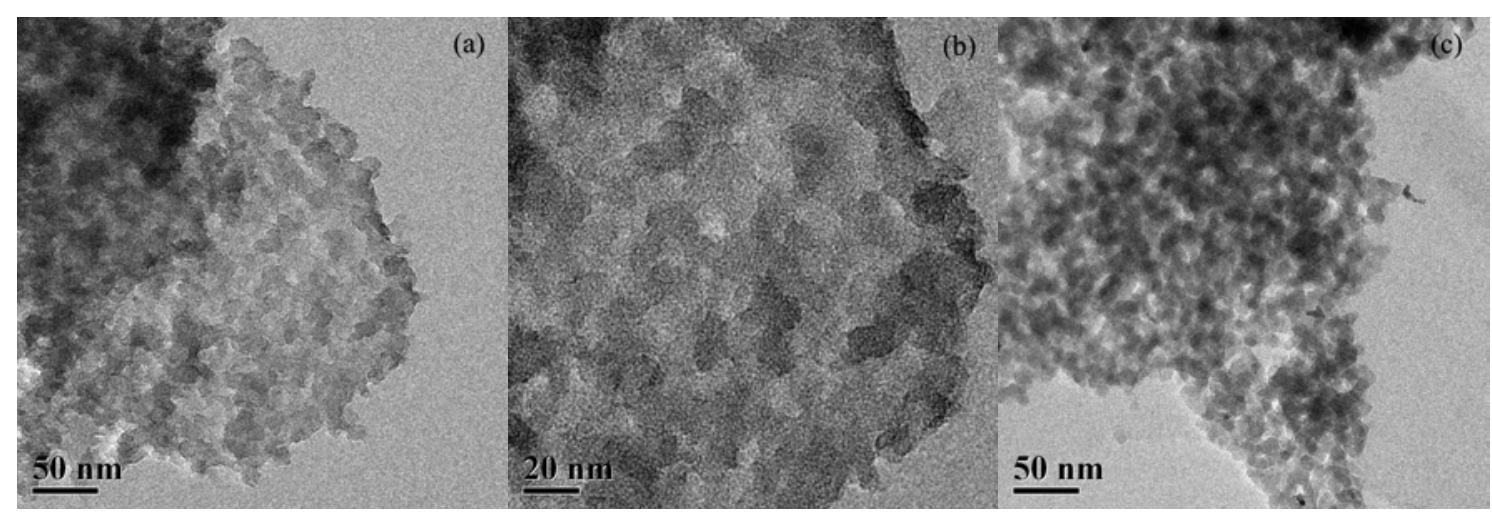

Fig. 5. TEM images of Rh/KAPs-1 (a,b) and $\mathrm{Rh} / \mathrm{SiO}_{2}$ (c) catalysts. 
Table 2

Hydroformylation of higher olefins over Rh/KAPs-1 and $\mathrm{Rh} / \mathrm{SiO}_{2}$ catalysts.

\begin{tabular}{|c|c|c|c|c|c|c|c|}
\hline \multirow{2}{*}{ Catalyst } & \multirow{2}{*}{ Substrate } & \multirow{2}{*}{ Conversion (\%) } & \multicolumn{3}{|c|}{ Selectivity (\%) } & \multirow{2}{*}{ Yield (\%) } & \multirow{2}{*}{$1 / \mathrm{b}$ ratic } \\
\hline & & & Aldehydes & Paraffins & Iso-olefins & & \\
\hline Rh/KAPs-1 & & $>99$ & 57 & 5 & 38 & 57 & 0.83 \\
\hline $\mathrm{Rh} / \mathrm{SiO}_{2}$ & & 99 & 26 & 10 & 64 & 26 & 1.01 \\
\hline Rh/KAPs-1 & & 99 & 42 & 24 & 34 & 42 & 0.51 \\
\hline $\mathrm{Rh} / \mathrm{SiO}_{2}$ & & 79 & 34 & 28 & 39 & 27 & 0.76 \\
\hline Rh/KAPs-1 & & 78 & 51 & 23 & 26 & 40 & 0.58 \\
\hline $\mathrm{Rh} / \mathrm{SiO}_{2}$ & & 51 & 47 & 25 & 28 & 24 & 0.78 \\
\hline Rh/KAPs-1 & & 62 & 63 & 18 & 19 & 39 & 0.73 \\
\hline $\mathrm{Rh} / \mathrm{SiO}_{2}$ & & 38 & 47 & 23 & 30 & 18 & 0.94 \\
\hline
\end{tabular}

Reaction conditions: autoclave reactor, pressure held at $2.0 \mathrm{MPa}$ by injection of premixed gas $\left(\mathrm{CO}: \mathrm{H}_{2}=1: 1\right)$ via a pressure regulator, $T=373 \mathrm{~K}, t=4 \mathrm{~h}$, substrate/catalyst $(\mathrm{S} / \mathrm{C})$ molar ratio $=3000$.

spectra of the $\mathrm{Rh} / \mathrm{SiO}_{2}$ catalysts, the peak at $2056 \mathrm{~cm}^{-1}$ was assigned to linearly adsorbed CO, and the peaks at 2096 and $2027 \mathrm{~cm}^{-1}$ were due to the anti-symmetrical and symmetrical vibrations of geminal $\mathrm{Rh}(\mathrm{CO})_{2}$ [26-28]. Based on these results, it was concluded that the Rh/KAPs-1 catalyst could form homogeneous active species for the reaction, while linear adsorbed $\mathrm{CO}$ and geminal $\mathrm{Rh}(\mathrm{CO})_{2}$ were observed on the $\mathrm{Rh} / \mathrm{SiO}_{2}$ catalyst. The formation of homogeneous active species was due to the high dispersion of the $\mathrm{Rh}$ species coordinated to the phosphorous atom in KAPs-1.

\subsection{Catalytic activity}

For comparison, the $\mathrm{Rh} / \mathrm{KAPs}-1$ and $\mathrm{Rh} / \mathrm{SiO}_{2}$ catalysts were tested for the hydroformylation of higher olefins. As listed in Table 2, the Rh/KAPs- 1 catalyst exhibited better activity and selectivity to aldehydes in hydroformylation: 1-hexene ( $>99 \%$ conversion, $57 \%$ selectivity to aldehydes); 1 -octene ( $99 \%$ conversion, $42 \%$ selectivity to aldehydes); 1 -decene (78\% conversion, $51 \%$ selectivity to aldehydes); 1 -dodecene ( $62 \%$ conversion, $63 \%$ selectivity to aldehydes). The difference in the sup-

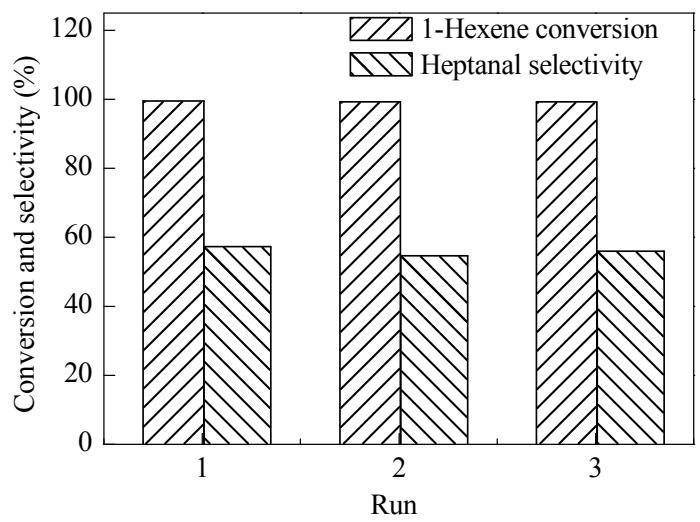

Fig. 8. Recycle of the Rh/KAPs-1 catalyst for the hydroformylation of 1-hexene. port led to the different activity between the Rh/KAPs-1 and $\mathrm{Rh} / \mathrm{SiO}_{2}$ catalysts. As illustrated above, a high surface area and hierarchical porosity were beneficial for heterogeneous catalysis, while the in situ formation of homogeneous active species $[29,30]$ improved the catalytic activity for hydroformylation. The recyclability of the Rh/KAPs- 1 catalyst was tested for the hydroformylation of 1-hexene (Fig. 8). The Rh/KAPs-1 catalyst can be reused with negligible loss of activity, and the Rh species in the filtrate was $0.3 \%$ in the first recycle.

\section{Conclusions}

The Rh/KAPs- 1 catalyst displayed high activity for the hydroformylation of higher olefins. Compared to the $\mathrm{Rh} / \mathrm{SiO}_{2}$ catalyst, Rh/KAPs-1 possessed highly dispersed Rh nanoparticles on the surface of KAPs-1 and formed homogeneous active species during the reaction. KAPs have a simple synthesis method and cheap reagents, and different kinds of monomers can be used to obtain different functional polymers. Further studies are needed on how to use KAPs efficiently.

\section{Acknowledgments}

We appreciate Prof. Tao Li for helpful discussions and beneficial support.

\section{References}

[1] Franke R, Selent D, Börner A. Chem Rev, 2012, 112: 5675

[2] Hebrard F, Kalck P. Chem Rev, 2009, 109: 4272

[3] Zeng Y, Wang Y H, Xu Y C, Song Y, Zhao J Q, Jiang J Y, Jin Z L. Chin J Catal (曾艳, 王艳华, 徐贻成, 宋颖, 赵家骐, 蒋景阳, 金子林. 催 化学报), 2012, 33: 402

[4] Cole-Hamilton D J. Science, 2003, 299: 1702

[5] Maschmeyer T, Rey F, Sankar G, Thomas J M. Nature, 1995, 378: 159

[6] Neves Â C B, Calvete M J F, Pinho e Melo T M V D, Pereira M M. Eur J Org Chem, 2012, 2012: 6309 


\title{
Graphical Abstract
}

Chin. J. Catal., 2014, 35: 1456-1464 doi: 10.1016/S1872-2067(14)60068-1

\section{Rh catalysts supported on knitting aryl network polymers for the} hydroformylation of higher olefins

Miao Jiang, Yunjie Ding *, Li Yan, Xiangen Song, Ronghe Lin Dalian Institute of Chemical Physics, Chinese Academy of Sciences; University of Chinese Academy of Sciences

Rh catalysts supported on knitting aryl network polymers (KAPs) showed high activity for the hydroformylation of higher olefins.

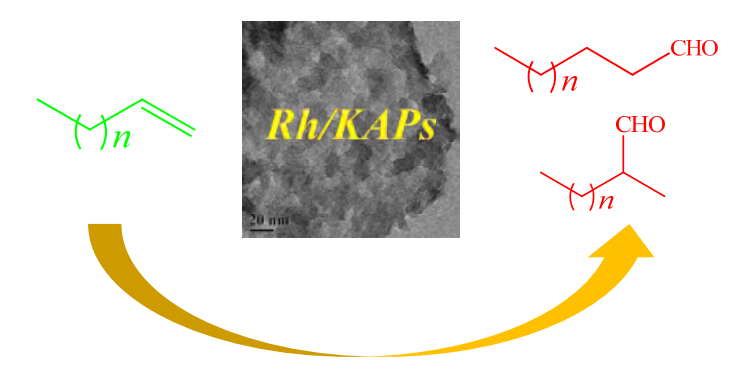

[7] Zhang J X, Huang G W, Zhang C, He Q H, Huang C, Yang X, Song H Y, Liang Z X, Du L, Liao S J. Chin J Catal (张嘉熙, 黄高伟, 张琤, 何群 华, 黄超, 杨旭, 宋慧宇, 梁振兴, 杜丽, 廖世均. 催化学报), 2013, 34: 1519

[8] Li X F, Zhang W J, Zhang L M, Yang H Q. Chin J Catal (李晓菲, 张文 娟, 张丽敏, 杨恒权. 催化学报), 2013, 34: 1192

[9] Zhang Y, Riduan S N. Chem Soc Rev, 2012, 41: 2083

[10] Liu Y, Lü Y C, Luo G S. Chin J Catal (刘荣, 吕阳成, 骆广生. 催化学 报), 2013, 34: 1635

[11] Wu T B, Zhang P, Ma J, Fan H L, Wang W T, Jiang T, Han B X. Chin J Catal (吴天斌, 张鹏, 马珺, 柇红雷, 王伟涛, 姜涛, 韩布兴. 催化 学报), 2013, 34: 167

[12] Wu D C, Xu F, Sun B, Fu R W, He H K, Matyjaszewski K. Chem Rev, 2012, 112: 3959

[13] Xie Y, Wang T T, Liu X H, Zou K, Deng W Q. Nat Commun, 2013, 4: 2960

[14] Chen X H, Qiao S L, Du Z K, Zhou Y H, Yang R Q. Macromol Rapid Commun, 2013, 34: 1181

[15] Chen L, Yang Y, Jiang D L. J Am Chem Soc, 2010, 132: 9138

[16] Ding S Y, Gao J, Wang Q, Zhang Y, Song W G, Su C Y, Wang W. J Am Chem Soc, 2011, 133: 19816

[17] Li B Y, Gong R N, Wang W, Huang X, Zhang W, Li H M, Hu C X, Tan B. Macromolecules, 2011, 44: 2410

[18] Li B Y, Guan Z H, Wang W, Yang X J, Hu J L, Tan B, Li T. Adv Mater,
2012, 24: 3390

[19] Dawson R, Stevens L A, Drage T C, Snape C E, Smith M W, Adams D J, Cooper A I. J Am Chem Soc, 2012, 134: 10741

[20] Luo Y L, Li B Y, Wang W, Wu K B, Tan B. Adv Mater, 2012, 24: 5703

[21] He W H, Zhang F, Li H. Chem Sci, 2011, 2: 961

[22] Mukhopadhyay K, Mandale A B, Chaudhari R V. Chem Mater, 2003, 15: 1766

[23] Walczuk E B, Kamer P C J, van Leeuwen P W N M. Angew Chem Int Ed, 2003, 42: 4665

[24] Gerritsen L A, Van Meerkerk A, Vreugdenhil M H, Scholten J J F. J Mol Catal, 1980, 9: 139

[25] Yan L, Ding Y J, Zhu H J, Xiong J M, Wang T, Pan Z D, Lin L W. J Mol Catal A, 2005, 234: 1

[26] Zhu H J, Ding Y J, Yin H M, Yan L, Xiong J M, Lu Y, Luo H Y, Lin L W. Appl Catal A, 2003, 245: 111

[27] Yan L, Ding Y J, Lin L W, Zhu H J, Yin H M, Li X M, Lu Y.J Mol Catal A, 2009, 300: 116

[28] Li X M, Ding Y J, Jiao G P, Li J W, Lin R H, Gong L F, Yan L, Zhu H J. Appl Catal A, 2009, 353: 266

[29] Li X M, Ding Y J, Jiao G P, Li J W, Yan L, Zhu H J. Chin J Catal (李显明, 丁云杰, 焦桂平, 李经伟, 严丽, 朱何俊. 催化学报), 2008, 29: 1193

[30] Yan L, Ding Y J, Liu J, Zhu H J, Lin L W. Chin J Catal (严丽, 丁云杰, 刘佳, 朱何俊, 林励吾. 催化学报), 2011, 32: 31

\section{编织芳基网络聚合物负载 $\mathrm{Rh}$ 催化剂上高碳烯烃氢甲酰化反应性能}

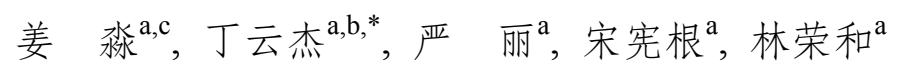 \\ ${ }^{\mathrm{a}}$ 中国科学院大连化学物理研究所洁净能源国家实验室(筹), 辽宁大连 116023 \\ $\mathrm{b}$ 中国科学院大连化学物理研究所催化基础国家重点实验室, 辽宁大连 116023 \\ ${ }^{\mathrm{c}}$ 中国科学院大学, 北京 100049
}

摘要: 考察了编织芳基网络聚合物(KAPs)负载的Rh催化剂(Rh/KAPs)在高碳烯烃氢甲酰化反应中的催化性能. 结果表明, 三苯基 膦-苯基底KAPs 负载 $\mathrm{Rh}$ 催化剂( $\mathrm{Rh} / \mathrm{KAPs}-1)$ 具有优异的高碳烯烃氢甲酰化反应活性, 产物醛收率显著高于 $\mathrm{Rh} / \mathrm{SiO}_{2}$ 催化剂. 傅里叶 变换红外光谱、热重、氮气吸附-脱附、X射线衍射、透射电子显微镜、 ${ }^{13} \mathrm{C}$ 核磁共振和 ${ }^{31} \mathrm{P}$ 核磁共振结果显示, Rh/KAPs-1催化剂 具有优异的热稳定性及大的比表面积和多级孔道结构, Rh颗粒处于高度分散状态, 并可在反应过程中形成均相催化活性物种.

关键词: 三苯基膦；编织芳基网络聚合物；铑；多相催化剂；高碳烯烃氢甲酰化

收稿日期: 2014-01-23. 接受日期: 2014-02-26. 出版日期: 2014-09-20.

*通讯联系人. 电话/传真: (0411)84379143; 电子信箱: dyj@dicp.ac.cn

本文的英文电子版由Elsevier出版社在ScienceDirect上出版(http://www.sciencedirect.com/science/journal/18722067). 


\section{1. 前言}

氢甲酰化反应是由过渡金属羰基化合物催化的烯 烃与合成气生成比原料烯烃高一个碳的醛或醇的反 应 $^{[1-3]}$, 它是迄今为止均相催化工业应用的最成功典范 之一. 均相催化体系虽然具有较高的催化活性和温和的 反应条件, 但催化剂同反应物料分离困难, 阻碍了其大 规模工业化应用 ${ }^{[4]}$. 比较而言, 多相催化剂与反应物料 容易分离, 但催化活性和选择性较低. 均相催化剂固载 化一直是氢甲酰化的研究热点 ${ }^{[5-8]}$, 固载化催化剂既具 有均相催化剂优良的反应活性又具有多相催化剂易于 分离的优点. 研究的固载化载体主要包括无机载体(分 子管、活性炭和 $\mathrm{SiO}_{2}$ 等)和有机聚合物载体, 其中有机聚 合物载体因具有高比表面积、低骨架密度以及易于引入 有机官能团等优点而备受关注 ${ }^{[9-11]}$.

相比于无机多孔材料, 有机聚合物易于在碳链中引 入各种官能团, 从而有利于合成有目的性的功能化材料; 且有机聚合物比金属有机骨架材料(MOFs)的热稳定性 高, 为在多相催化领域的应用提供了保障. 目前, 有机聚 合物主要包括超交联聚合物(HCPs)、固有微孔聚合物 (PIMs)、共轭微孔聚合物(CMPs)和共价有机骨架材料 $(\mathrm{COFs})^{[12]}$. 近年来, 这些有机聚合物材料广泛应用于物 质分离和气体吸附等领域 ${ }^{[13,14]}$, 而在多相催化领域的应 用仍处于起步阶段 ${ }^{[15,16]}$.

编织芳基网络聚合物(KAPs)是华中科技大学谭必 恩课题组 ${ }^{[17-20]}$ 于 2011 年合成的新型微孔有机聚合物. $\mathrm{KAPs}$ 是以三苯基膦作为单体, 引入芳香族化合物(如苯、 甲苯、联苯和 $1,3,5$-三苯基苯等)作为共单体, 外加交联剂 二甲氧基甲烷, 利用 $\mathrm{FeCl}_{3}$ 催化的傅-克反应一步形成的 微孔聚合物. 该材料合成方法简单, 原料价格低廉, 最重 要的是通过调变单体和共单体的种类, 可以获得各种功 能化的聚合物材料. 本文将KAPs 用于负载金属 Rh形成 多相催化剂( Rh/KAPs), 系统考察了该催化剂在氢甲酰 化反应中的催化性能.

\section{2. 实验部分}

\section{1. 载体KAPs的合成}

合成 4 种共单体不同的KAPs样品. 将三苯基膦 $(15.75 \mathrm{~g}, 0.06 \mathrm{~mol})$ 和苯 $(4.68 \mathrm{~g}, 0.06 \mathrm{~mol})$ 加入到 1,2 -二氯 乙烷 $(100 \mathrm{ml})$ 溶液中, 再分别加入二甲氧基甲烷 $(9.12 \mathrm{~g}$, $0.12 \mathrm{~mol})$ 和无水 $\mathrm{FeCl}_{3}(29.25 \mathrm{~g}, 0.18 \mathrm{~mol})$. 室温下摚拌 至完全溶解, 升温至 $318 \mathrm{~K}$ 搅拌 $5 \mathrm{~h}$ 形成基本的交联网络,
再升温至 $353 \mathrm{~K} 反$ 应 $67 \mathrm{~h}$. 得到的沉淀用乙醇洗涤 3 次并 索氏提取 $24 \mathrm{~h}$, 最后在 $343 \mathrm{~K}$ 真空干燥 $24 \mathrm{~h}$, 即得三苯基 膦-苯编织芳基网络聚合物KAPs-1. 将上述溶液中的苯 换成甲苯 $(5.52 \mathrm{~g}, 0.06 \mathrm{~mol})$, 同法制得三苯基膦-甲苯编 织芳基网络聚合物 KAPs-2. 将上述溶液中三苯基膦用 量改为 $5.25 \mathrm{~g}(0.02 \mathrm{~mol})$, 无水 $\mathrm{FeCl}_{3}$ 用量改为 $19.5 \mathrm{~g}(0.12$ $\mathrm{mol})$, 甲苯改为联苯 $(3.08 \mathrm{~g}, 0.02 \mathrm{~mol})$, 同法制得三苯基 膦-联苯编织芳基网络聚合物KAPs-3. 将上述溶液中联 苯改为 1,3,5-三苯基苯 $(6.12 \mathrm{~g}, 0.02 \mathrm{~mol})$, 同法制得三苯 基膦-1.3,5-三苯基苯编织芳基网络聚合物KAPs-4.

\section{2. 催化剂制备}

用定量的 $\mathrm{RhCl}_{3}$ 乙醇溶液分别浸渍 $\mathrm{KAPs}$ 和 $\mathrm{SiO}_{2}$ 载 体, 室温下阴干 $24 \mathrm{~h}, 393 \mathrm{~K}$ 干燥 $12 \mathrm{~h}$, 再在 $453 \mathrm{~K}$ 用 $\mathrm{H}_{2}$ 还 原 $4 \mathrm{~h}$, 最后在 $\mathrm{N}_{2}$ 下保存备用, 所得催化剂 $\mathrm{Rh} / \mathrm{KAPs}$ 和 $\mathrm{Rh} / \mathrm{SiO}_{2}$ 的 $\mathrm{Rh}$ 负载量均为 $1 \mathrm{wt} \%$.

\section{3. 催化剂表征}

样品的傅里叶变换红外光谱(FT-IR)测定在Bruker 公司的 Tensor 27 型红外光谱仪上进行, 分辨率为 4.0 $\mathrm{cm}^{-1}$, 32次扫描累加, 扫描范围 4000-400 $\mathrm{cm}^{-1}$. 样品的热 重(TG)实验在Netzsch STA 449F3 型热重分析仪上进行, 催化剂装填量为 $9.0 \mathrm{mg}$, 在 $\mathrm{N}_{2}$ 氛围下从 $293 \mathrm{~K}$ 升温至 923 $\mathrm{K}$, 升温速率 $10 \mathrm{~K} / \mathrm{min}$. 样品的比表面积和孔径分布测定 在Quantachrome Instruments 公司的Autosorb-1型吸附分 析仪上进行, 样品预先在 $373 \mathrm{~K}$ 处理 $20 \mathrm{~h}$, 孔径分布分析 采用NLDFT方法, 选用 carbon (slit pore)模型. 样品的X 射线衍射(XRD)测定在PANalytical公司的X'pert PRO型 $\mathrm{X}$ 射线衍射仪上进行, $\mathrm{Cu} K_{\alpha}$ 辐射源, 管压 $40 \mathrm{kV}$, 管流 40 $\mathrm{mA}$, 扫描速度 $10^{\circ} / \mathrm{min}$, 扫描范围 $2 \theta=10^{\circ}-70^{\circ}$. 样品的透 射电镜(TEM)测定在日本JEOL公司JEM-2000EX型透射 电子显微镜上进行. 样品的 ${ }^{13} \mathrm{C}$ 固体核磁实验 $\left({ }^{13} \mathrm{C} \mathrm{MAS}\right.$ NMR) 在VARIAN公司Infinityplus型核磁共振波谱仪上 进行, $2.5 \mathrm{~mm} \mathrm{ZrO}$ 转子, 弛豫延迟时间 $3.0 \mathrm{~s}$, 转动频率 12 $\mathrm{kHz}$. 样品的 ${ }^{31} \mathrm{P}$ 固体核磁实验 ${ }^{31} \mathrm{P}$ MAS NMR)仪器同上, $2.5 \mathrm{~mm} \mathrm{ZrO}_{2}$ 转子, 振动频率 $161.8 \mathrm{MHz}$, 弛豫延迟时间 $3.0 \mathrm{~s}$, 转动频率 $10 \mathrm{kHz}$, 以 $85 \% \mathrm{H}_{3} \mathrm{PO}_{4}$ 为化学位移的参考 外标. 样品的 CO吸附原位FT-IR测定在Bruker公司的 Tensor 27 型红外光谱仪上进行, 分辨率 $4.0 \mathrm{~cm}^{-1}, 32$ 次扫 描累加, 扫描范围 4000-400 $\mathrm{cm}^{-1}$. 首先, 样品在 $393 \mathrm{~K}$ 用 $\mathrm{H}_{2}(40 \mathrm{ml} / \mathrm{min})$ 还原 $1 \mathrm{~h}$, 随后切换成 $\mathrm{N}_{2}(40 \mathrm{ml} / \mathrm{min})$ 吹扫 $0.5 \mathrm{~h}$, 扫描谱图记为谱图 $\mathrm{A}$. 然后, 将 $\mathrm{N}_{2}$ 切换成 $\mathrm{CO}(40$ $\mathrm{ml} / \mathrm{min}$ ) 吹扫 $0.5 \mathrm{~h}$, 随后再切换成 $\mathrm{N}_{2}$ 吹扫 $0.5 \mathrm{~h}$, 扫描谱图 记为谱图 $\mathrm{B}$. 谱图 $\mathrm{B}$ 与谱图 $\mathrm{A}$ 的差谱即为样品吸附 $\mathrm{CO}$ 的 
原位FT-IR谱.

\section{4. 催化剂评价}

高碳烯烃氢甲酰化评价反应在 $30 \mathrm{ml}$ 哈氏合金高压 釜中进行．将 $11.1 \mathrm{mg}$ 催化剂、一定量的高碳烯烃和 $6 \mathrm{~g}$ 甲苯溶剂在惰性气氛下加入到高压釜中。用合成气 $\left(\mathrm{CO}: \mathrm{H}_{2}=1: 1\right)$ 置换釜内气体 3 次, 充入合成气, 升温至 373 $\mathrm{K}$ 进行反应. 反应进程中, 打开进气阀, 关闭出气阀, 通 过调压阀不断补充气体, 使釜内压力始终保持在 2.0 $\mathrm{MPa}$. 反应物在磁力搅拌下反应 $4 \mathrm{~h}$, 采用离心方法分离 产物与催化剂. 分离后的产物以正丙醇为内标物, 在 Agilent 7890A型气相色谱仪上, 使用配有HP-5毛细柱的 氢火焰检测器(FID)分析.

\section{3. 结果与讨论}

\section{1. 催化剂的表征结果}

\subsubsection{FT-IR结果}

图1示出了分别以苯、甲苯、联苯和1,3,5-三苯基苯 作为共单体合成的KAPs样品以及KAPs-1负载Rh的多相 催化剂 Rh/KAPs-1 的FT-IR 谱. 其中, 在 $1600-1450 \mathrm{~cm}^{-1}$ 附近的峰与苯环的骨架伸缩振动有关; 在 1250-950和 900-650 $\mathrm{cm}^{-1}$ 附近的峰由苯环 $\mathrm{C}-\mathrm{H}$ 面内弯曲振动和苯环 $\mathrm{C}-\mathrm{H}$ 面外弯曲振动所形成. 同时, 在 $1435 \mathrm{~cm}^{-1}$ 的振动峰 归属为 $\mathrm{P}-\mathrm{CH}_{2}$ 键的伸缩振动 ${ }^{[21]}$, 表明三苯基膦作为单体 存在于微孔聚合物骨架中. 从图1还可以看出, KAPs-1 和 $\mathrm{Rh} / \mathrm{KAPs}-1$ 的谱图基本一致, $\mathrm{P}-\mathrm{CH}_{2}$ 键的伸缩振动峰 $\left(1435 \mathrm{~cm}^{-1}\right)$ 显著地得以保留, 说明在催化剂制备过程中 没有破坏KAPs-1的基本结构.

\subsubsection{TG结果}

良好的热稳定性是聚合物材料用作多相催化剂载 体的重要条件. 图 2 为 Rh/KAPs-1催化剂的 TG曲线. 可 以看出, 在 $600 \mathrm{~K}, \mathrm{Rh} / \mathrm{KAPs}-1$ 催化剂未出现明显的热分 解现象, 表明其具有高的热稳定性, 同目前聚合物材料 中热稳定性优异的 Nafion NR50 (600 K) 相当. 因此, KAPs-1可用于多相催化反应中.

\subsection{3. 比表面积和孔结构}

如表1所示, 苯作为共单体形成的KAPs-1负载的 $R h$ 催化剂具有最大的比表面积 $723 \mathrm{~m}^{2} / \mathrm{g}$, 而 $\mathrm{Rh} / \mathrm{SiO}_{2}$ 催化剂 为 $187 \mathrm{~m}^{2} / \mathrm{g}$. 图 3 为 $\mathrm{Rh} / \mathrm{KAPs}-1$ 催化剂的吸附-脱附等温 线和孔径分布图. 可以看出, 在相对低压区域 $\left(p / p_{0}<\right.$ $0.001), \mathrm{N}_{2}$ 吸附量显著增加, 表明存在大量微孔; 有滞后 环暗示有介孔存在; 同时在中高压区域 $\left(p / p_{0}=0.6-1.0\right)$ $\mathrm{N}_{2}$ 吸附量明显上升, 表明有大孔存在, 正如图3(b)所示.
实际上, 这种多级孔道结构和大比表面积十分有利于多 相催化反应的进行：大比表面积和丰富的微孔结构可以 使活性组分高度分散于载体材料上, 同时介孔和大孔的 存在有利于传质的进行.

\subsubsection{XRD和TEM结果}

图4为KAPs-1和 Rh/KAPs-1的XRD谱. 除了 KAPs-1 的空白峰之外, 未检测到新的衍射峰. 这可能是由于 Rh/KAPs-1样品中Rh颗粒高度分散或Rh负载量太低, 低 于XRD检测限. 图 5 是 $\mathrm{Rh} / \mathrm{KAPs}-1$ 和 $\mathrm{Rh} / \mathrm{SiO}_{2}$ 的TEM照片. 由图可见, 相对于 $\mathrm{Rh} / \mathrm{SiO}_{2}$ 样品, $\mathrm{Rh} / \mathrm{KAPs}-1$ 样品中 $\mathrm{Rh}$ 颗 粒更加分散.

\subsection{5. ${ }^{13}$ C MAS NMR 和 ${ }^{31} P$ MAS NMR结果}

由Rh/KAPs-1催化剂的 ${ }^{13} \mathrm{C}$ MAS NMR谱(图6(a))可 见, 在 $\delta=42.1$ 附近的峰归属为傅-克反应形成的亚甲基 的碳, 在 $\delta=137.5$ 和 129.5 附近的峰分别归属为苯环取代 碳和未取代碳 ${ }^{[18]}$. 比较KAPs-1和Rh/KAPs-1的 ${ }^{31} \mathrm{P}$ MAS NMR谱 (图6(b)), 振动峰从26.1移到27.3, 这可能是因为 KAPs-1中三苯基膦上的P原子同负载的金属 $\mathrm{Rh}$ 发生了 相互作用 ${ }^{[22,23]}$. 此种聚合物不但具有高的比表面积和多 级孔道结构, 而且聚合物骨架中包含有机配体三苯基膦, 它可以同高分散于载体表面的金属 $\mathrm{Rh}$ 发生相互作用.

\subsubsection{CO吸附原位FT-IR结果}

图7为 $\mathrm{Rh} / \mathrm{KAPs}-1$ 和 $\mathrm{Rh} / \mathrm{SiO}_{2}$ 的CO吸附原位FT-IR谱. $\mathrm{Rh} / \mathrm{KAPs}-1$ 催化剂上的 2081 和 $2004 \mathrm{~cm}^{-1}$ 吸附峰归属为 均相氢甲酰化活性物种 $\mathrm{HRh}(\mathrm{CO})\left(\mathrm{PPh}_{3}\right)_{3}{ }^{[24,25]} ; \mathrm{Rh} / \mathrm{SiO}_{2}$ 催化剂上的 $2056 \mathrm{~cm}^{-1}$ 吸收峰对应于线式吸附 $\mathrm{CO}$, 而 2096 和 $2027 \mathrm{~cm}^{-1}$ 附近的双吸收峰归属为孪式吸附CO的 反对称和对称振动 ${ }^{[26-28]}$. 结果表明, 在接近反应条件的 环境中, Rh/KAPs-1催化剂上可捕捉到均相催化的活性 物种, 而 $\mathrm{Rh} / \mathrm{SiO}_{2}$ 催化剂上只能观测到 $\mathrm{CO}$ 在金属 $\mathrm{Rh}$ 上的 线式吸附和孪式吸附. Rh/KAPs-1 上的均相催化活性物 种是由负载的金属 $\mathrm{Rh}$ 同存在于微孔聚合物骨架中三苯 基膦上的P原子在反应过程中原位生成的.

\section{2. 氢甲酰化反应活性}

为了比较 $\mathrm{Rh} / \mathrm{KAPs}-1$ 和 $\mathrm{Rh} / \mathrm{SiO}_{2}$ 的催化性能, 将它们 用于高碳烯烃的氢甲酰化反应中. 由表 2 可见, Rh/KAPs-1催化剂在1-已烯(转化率 > 99\%, 庚醛选择性 $57 \%$ )、1-辛烯(转化率99\%, 壬醛选择性 $42 \%$ )、1-癸烯(转 化率 $78 \%$, 十一醛选择性 $51 \%$ ) 和 1-十二烯(转化率 $62 \%$, 十三醛选择性 $63 \%$ )氢甲酰化反应中具有优异的烯烃转 化率和产物醛选择性, 明显优于 $\mathrm{Rh} / \mathrm{SiO}_{2}$ 催化剂. 其原因 主要在于两种催化剂载体的不同. 如前所述, KAPs-1具 
有高比表面积和多级孔道结构, 因而适合用作载体应用 于多相催化反应; 另外, 存在于微孔骨架中的三苯基膦 配体同高分散的金属Rh原位生成均相催化反应的活性 物种 ${ }^{[2,30]}$, 从而提高了氢甲酰化反应活性. 循环实验表 明, 在1-已烯氢甲酰化中, Rh/KAPs-1 催化剂循环使用 3 次(图8), 其催化活性未见明显变化, 第一次循环实验后 母液中金属 $R h$ 流失量为 $0.3 \%$.

\section{4. 结论}

$\mathrm{Rh} / \mathrm{KAPs}-1$ 催化剂在高碳烯烃氢甲酰化反应中具有 优异的催化活性, 明显优于 $\mathrm{Rh} / \mathrm{SiO}_{2}$ 催化剂. 这是由于金
属活性组分高度分散于具有大比表面积的KAPs-1上; 同时, KAPs- 1 可以同金属Rh在反应过程中形成与均相 催化剂相同的活性物种. KAPs-1 作为一种新兴的微孔 聚合物, 其合成方法简单, 原料价格低廉, 易于引入对反 应有利的化学官能团, 因此近一年多来引起了人们高度 关注. 如何将其有效地应用于多相催化反应还有待进一 步深入研究.

\section{致谢}

本文得到了华中科技大学李涛教授积极的讨论和 指导, 特此鸣谢. 